\title{
Bosses of the Wooden Vaulting of the Eastern Walk of the Cloister of Lincoln Minster
}

the Rev. Precentor Venables M.A.

To cite this article: the Rev. Precentor Venables M.A. (1890) Bosses of the Wooden Vaulting of the Eastern Walk of the Cloister of Lincoln Minster, Archaeological Journal, 47:1, 220-228, DOI: 10.1080/00665983.1890.10852427

To link to this article: http://dx.doi.org/10.1080/00665983.1890.10852427

Published online: 15 Jul 2014.

Submit your article to this journal $\sqsubset$

Q View related articles $\square$ 


\section{BOSSES OF THE WOODEN VAULTING OF THE EASTERN WALK OF THE CLOISTER OF LINCOLN MINSTER.}

By the REV. PRECENTOR VENABLES, M.A.

The works in connection with the restoration of the Chapter House of Lincoln Minster, now all but completed, rendered it necessary to take down and rebuild the eastern walk of the cloisters. This work had been previously accomplished for the other two existing walks, the fourth, or north walk having long since fallen down and been rebuilt by Sir Christopher Wren. An opportunity was thus offered for a close examination of the bosses of the wooden groining. Photographs of the whole series were taken by Mr. Hadley, of Lincoln, reduced copies of which were published in the "Builder" July 19th of the current year.

These bosses which belong to quite the close of the thirteenth century are of exquisite design and execution, the pose of some of the figures and the flow of the drapery exhibiting a grace and refinement which it would be difficult to surpass. Exposure to the weather for several centuries has robbed the carvings of much of their original sharpness, and in some instances has caused decay and mutilation. But even in their damaged state they prove themselves to be the works of no ordinary artist, whose eye for beauty of form was combined with vigour of conception and ready skill of hand, and a true feeling for nature. The designs, especially those representing the months are charmingly spirited and natural, characterized by that " uncalculating bestowal of the wealth of labour" which Mr. Ruskin speaks of as one of the special features of medirval carving. They are zot dead prosaic fashionings of the mallet and the chisel. 
They live and move. What must the instinctive feeling for art in the ordinary English workman have been, when such exquisite carvings came naturally from his hands, not to be placed near the eye and gazed at and admired, but to be fixed high above the head, as mere architectural decorations, adding to the general effect, but not challenging the individual notice which we now feel they so richly deserve.

The basses in question are nineteen in number, alternately larger and smaller, fixed at the point of junction of the ribs of the slight wooden groining. The eastern walk to which they belong consists of nine narrow bays, with one wider bay at the southern extremity, corresponding to the width of the southern walk. A tenth narrow bay, and the wider extreme bay have been swallowed up in Wren's Roman Doric cloister, which supports Dean Honywood's library. The subjects are as follows-

(1). Much mutilated; one of the series of the months, perhaps October, the tree-felling month, or March the pruning month. It represents a man, now headless, in a long flowing frock girt round his waist, grasping in his two hands the handle of an axe or some sharp cutting instrument, now lost, which he is about to bring down on the trurik of a tree standing at his right hand. The action in spite of the mutilation of the boss is clearly discernible, and looks too vigorous for pruning.

(2). (small) A short fat man with long curls dependent over his ears, and a short beard, seated with his hands on his knees, as though in front of a fire, his countenance indicating a sense of complete satisfaction. Possibly intended to represent "cold February," for which a man warming himself before a chimney-place was the recognised symbol.

(3). The month of November is typified by a man sowing corn. He wears a long loose frock, ${ }_{3}$ girt about the waist; on his head is a flat cap, and a muffler protects his cheeks and chin. On his left side he carries a broad, shallow basket of seed corn, suspended by a strap passing over his right shoulder. He scatters the seed broadcast with his right hand; a sack of corn is behind him to his right. This figure is very spirited; the action vigorous; the face shews much character. 
(4). (small) Two winged dragonlike animals fighting; each seeking to devour the other.

(5). The month of December typified by pig-killing, recalling old Tusser's lines :-

\section{When mast is gone \\ Hog falleth anon.}

The killer is an old man with a long beard, his head covered with a close fitting coif, He wears a loose frock, with a girdle round the waist. His right arm is raised in act of striking a huge swine, who is contentedly munching acorns. The axe is gone. The back of the boss represents oak leaves and acorns beautifully carved, but out of proportion with the rest of the design.

(6). (small) A male lamb scratching its nose with its right hind foot.

(7). The month of January, the month of good cheer; a prolongation of the Christmas festivity. The subject is in agreement with Chaucer's lines

\section{"Janus sits by the fyre with double berd}

And drinketh of his bugle horn the wyn."

Franklein's Tale, 516.

A man clad in a long loose tunic, ungirt, that he may drink more at his ease, his head covered with a broad flat slouching cap, with a hood reaching over his head and protecting his chin, is sitting cross legged, holding a drinking horn in his left hand and a bowl in his right, resting his elbow on a pitcher. Behind him is a cask of ale with a spigot, to replenish his bowl. The man's thorough enjoyment of his surroundings is very marked.

(8). (small) A very singular group probably intended to portray Ezekiel's four living creatures. It consists of four small squat draped figures, the upper part human, the bodies almost non-existent, the extremities those respectively of the ox, the lion, the eagle, and the man. The heads of three are hooded, the fourth wears a peaked cap ; all are gazing upwards.

(9). Two dragon like creatures in fierce conflict, each biting the other's neck.

(10). (small) another subject from Ezekiel's vision, a figure, broad for its height, combining the ox and the lion below, and the human form above. It has a female 
head in a thirteenth century square headdress, the cheeks and chin wrapped in a wimple, and long flowing drapery falling over each ear. The bust is fully vested, the lrapery flowing over the breasts. The being has no body, but two sets of extremities; to its right the hoofed feet of an ox, and a tail ending in a leaf; and on its left the paws and tail of a lion.

(11). Our Lord in act of Benediction. He is seated on a cushioned throne, the uprights ending in finials. $\mathrm{He}$ is fully vested, the pallium fastened with a diamond shaped morse, His feet are bare, His hair is long and curling; the beard short. The right hand is raised in blessing; in the left hand He carries the world, represented as a flat disk.

(12). (The central boss over the Chapter House door.) A very solemn looking, long-eared rabbit, in a crouching attitude; his head and shoulders are invested with a close fitting covering, puckered at the neck, with holes for the ears and eyes, the very ideal of "Brer Rabbit" of Uncle Remus' Tales.

(13). The Virgin and Child, throned; an exquisitely graceful composition. The Virgin veiled and crowned is seated and carries the Holy Child on her left knee. Her flowing veil passes under her chin from left to right; her right hand, and the head of our Lord have been destroyed. He holds a dove in His left hand, and raises His right hand in blessing ; a dove of a larger size is perched on the back of the throne to the left.

(14). (small, much mutilated, both the head and hands gone), a seated angel exquisitely draped, holding a erown in the left hand.

(15). The enthronement of the Blessed Virgin. Our Lord is seated, with long flowing hair and bearded, in a long tunic, girt round the waist, and reaching to the feet which are bare; His right hand raised in blessing, His left holding the world as before in the form of a disk. On the right hand sits the Virgin, half turning toward her Divine Son, the head unhappily gone. The treatment of this subject is surpassingly beautiful; the drapery shews much grace.

(16). (small, much mutilated) a grotesque. A tumbler performing his feats, holds his right foot - with his right 
hand, on a level with his shoulders, his left hand is on his knee.

(17). A large boss of vine leaves and grapes, exquisitely true to nature.

(18). A calf lying down, scratching its chin with its right hind foot.

(19). A mitred bishop-perhaps Oliver Sutton, the chief promoter of the cloisters,-seated on a cushioned throne, his right hand raised in blessing, bearing a mutilated crozier in his left hand.

It will have been noticed that only four of the months, or possibly five, are represented in the bosses of the East walk, which now come under our observation. The others may have perished on the fall of the Norch walk, or they may be still awaiting identification among the bosses of the other two walks, which have never yet received a thorough examination. There can however be but little doubt that the series was once complete, and embraced all the twelve months of the Kalendar. It is well known that representations of the months by their characteristic occupations are of very frequent occurrence in illuminated manuscripts and in early printed books.

The earliest known English example in carving is the Norman font at Burnham Deepdale, near Hunstanton in Norfolk, described and figured a century ago, 1790.) in the Archæologia, vol. x., p. $177 \mathrm{ff}$. A very similar series, accompanied by the signs of the Zodiac, occurs upon a leaden font at Brookland, Kent, between Rye and Romney, described and figured in the Archoeological Journal, vol. vi, p. 159, and in the Archoologia Cantiana, vol iv, p. $87 \mathrm{ff}$. The occupations of the months together with the signs of the Zodiac are also carved on the porch doorway of St. Margaret's Church, York, figured in Drake's Eboracum, p. 308, as well as by Cave and Carter, but most correctly by the late Mr. Browne, of York, in 1827.

The most complete series existing in stone, however, is that on the fourteenth century capitals of the twelve pillars of the choir of Carlisle Cathedral. Each bears, without a single break, a representation of the characteristic occupation of a separate month. The whole series has been most carefully described by Mr. James 
Fowler, F.S.A., in a paper in the Transactions of the Cumberland and Westmoreland Antiquarian Society for 1875-6, (vol. ii., part 2, pp. 281-296). To the same gentleman we are also indebted for an elaborate and exhaustive treatise on the "Mediæval Representations of the Months and Seasons," published in the Archoologia, vol. xliv., pp. 137-224.

Returning to Lincoln Cathedral, it may be mentioned that three of the months, March, April and July, are represented in stained glass in the quatrefoils of the east windows of the choir aisles. There can be no doubt that the series was once complete. They date from the close of the fourteenth or the beginning of the fifteenth century. March (Marche) is represented as a man in a short jerkin, girt at the waist, and closely fitting hose, and a slouch hat, engaged in pruning. He holds a pruning hook in his left hand. In his right he bends down a twig he is about to cut off. Three small fagots of the cuttings lie on the ground. Behind him is a square castle surmounted by two towers, one round, the other square. April (Auerill) has a young man handsomely dressed, in tightly fitting hose and shoes, and a tight short coat purffled round the hips, with long loose hanging sleeves, through holes in which his arms come out. On his left fist is perched a hawk ; in his right hand he holds a bunch of roses in full bloom. A small flat cap is on his head, beneath which his hair sticks out in bunches on either side. He is smoothly shaven, behind him to his left is a square castle on a mound, surmounted by a square turret with pyramidal roof. July (Iulii) the hay month of the Anglo Saxons, appropriately represents hay harvest.

\section{"Julius ergo secat gramen, fenumque reservat."}

To the left a man in a close fitting vest, the right sleevo folded back above the elbow, and his hose turned up above the knees, is mowing with a scythe held by its two handles. He wears on his head a low crowned broad brimmed hat, probably of straw. To the right a lad in a closely fitting tunic, girt ro:and the waist, is turning the grass with a fork. In the back ground are three conical hay cocks.

Two of the misereres of the upper range of stalls VOI, XIVII 
(erected by Treasurer John of Welton, c. 1380), on the north side are carved with subjects belonging to this series. : The miserere of the stall of Biggleswade has two men ploughing in the centre, with representations of harrowing to the left and sowing to the right. That of the stall of the Archdeacon of Huntingdon has the customary autumnal scene; a man beating down acorns in the centre, with swine feeding on either side.

The misereres of the choir of Worcester Cathedral supply a complete series of subjects which indicate if they do not actually represent the months of the year. The history of these carvings is curious. Believed to have been executed in 1379 , they were removed from their places in 1551 by King Edward's commissioners, restored and reset by Queen Mary's authority in 1556, and removed again at the beginning of the present century by Mr. St. John, the Treasurer to the Dean and Chapter, to be fixed upon the cornice of a "compo" organ screen then erected between the nave and choir. This wretched production was cleared away in 1865, and the misereres were refixed in the choir stalls. Unhappily the old arrangements had been entirely lost and they were placed in no definite order. The following is the arrangement given by Mr. Fowler (Mediæval representations of Months and Seasons p. 27), though he allows that in some cases the identification is not beyond question. The numbers, given, refer to the photographic representations of these carvings published by Mr. Bemrose of Derby.

JANUARY (?). A woman with a distaff, and a man digging with a spade.

"When Adam delved and Eve span

Who was then the gentleman?"

"In England" writes Mr. Fowler, the day after Twelfth Day, or the very end of the Yule Tide feastings, was called St. Distaff's Day, and was a special holiday for spinsters.

If the maids a spinning goe

Burne the flax and fire the tow.

Give St. Distaff all the right

Then give Christmas-sport good night. 
Februalix (1). An old man in a flat cap and wrapper over his ears and chin, his jacket closely buttoned up, seated on a semi-circular three-legged arm chair before a fire, at which he is warming his feet having taken off his boots, and is stirring a pot hanging over it. An embattled octagonal chimney appears above. The supporters represent, to the left a dog or cat warming itself, and to the right two flitches of bacon hung up to dry.

MARCH (11). A man sowing seed. He wears the same flat cap and jerkin which appears in all the subjects. His shoes are oddly pointed for the great toe only. $\mathrm{He}$ stands between two tall cylindical baskets, and has a seed bag on his left side strapped over his right shoulder; with his right hand he casts the seed. The supporters are two birds flying down to pick up the seed.

ApriL (?) (5). A bearded knight in complete armour, his sword in its sheath depending between his legs. He wears the same flat cap with it wrapper drawn over his ears and chin, and is enveloped in a loose cloak held together by a band above the waist. In each hand he carries a branch covered with roses.

MaY (30). A king or crowned personage with a cloak over his shoulders; his short coat is ungirt, he carries his gloves in his left hand, on his right fist there has been a hawk, of which the claws only are left; to his right a richly caparisoned horse is led by a page.

JUNE (18). Three men in flat caps, their hair frizzed out into wings on each side, are mowing with scythes; they stand upright, not bending to their work. The supporters are very curious, to the right a fox in a cloak kneels in prayer over a sheep's head, to the left a rabbit is going hunting, mounted on a greyhound.

JuLx (17). Three men with the same flat caps and frizzed hair stand weeding in the midst of standing corn. Their weeding tools are much mutilated. There are the remains of the prongs of a crotch near the left foot of two, and of the curved blade of a weed hook near the right foot of all three.

August (16). Three men, bare headed, are reaping corn with small curved sickles, and binding it into sheaves. The attitude and expression of the faces are extremely 
animated. As supporters there are three sheaves on either side.

SEPTEMBer (?). A huntsman sounds his horn which winds round his body.

OCtober (27). A man, his head covered by a hood, and his shoulders by a cape which comes down over his buttoned jerkin, beats down acorns with a staff held in his two hands, which two swine are munching below.

November (?). A sow suckling two young pigs, in preparation for the Christmas teast. Pork was the favourite winter food of the middle ages.

DeCEMBER (6). A butcher killing an ox, lying down before him, with an axe, the blunt part of which he is bringing down on the animal's head, the sharp blade being turned upwards. He wears an apron and sharp pointed shoes, and the usual flat cap; his sleeves are turned up.

At Malvern Abbey Church, interspersed among a number of carvings of other subjects, there are seven misereres very similar to those at Worcester, which may be identified with the months. For March (or November) there is a man sowing seed; for April a man holding in each hand a bunch of roses; for June a man mowing with a scythe; for July a man weeding out thistles from standing corn ; for September a man carrying a basket of fruit; for October a man beating down acorns which a boar on one side and on the other side a sow are eating; and finally, for December a man killing an ox. Several similar examples nccur in the misereres at Gloucester Cathedral, and on the lower frieze of the wooden watching loft on the nortl side of the feretory of St. Alban's. For fuller particulars I would refer to Mr. Fowler's admirable paper in the Archcoologia, already mentioned. I believe that he could now add many more examples to his list.'

\footnotetext{
${ }^{1}$ Canon Creighton informs me that he has met with a set of carved misereres of great excellence in the church of lipple
}

near Tewkesbury. They are fourteen in number, representing the Sun and Moon and, probably, the twelve months. 